\title{
Factors predicting financial security of female headed households
}

\begin{abstract}
In microeconomic perspective, financial security is often linked with the individual level of saving, the ability to meet the emergency, an adequate fund during retirement and the stability of income. Current macro economic volatility caused several consequences and indirectly affect on consumer saving and spending. Additionally, with a higher cost of living influenced consumers consumption especially among female-headed households with a number of dependents and dual domestic/work roles. This study investigates the relationships between financial strains, self-coping mechanisms, financial literacy, financial practices and financial security. A cross-sectional study of multistage random sampling has been used in the data collection. A structured questionnaire used in the survey method to collect data from 521 female-headed households from six single mothers associations in Malaysia. The results predicted that financial strains, self-coping mechanisms, financial literacy and financial practices explained $42.3 \%$ of the variance in financial security. The two strongest predictors are the self-coping mechanisms and financial practices. The implications of findings for policy makers, single mothers associations and financial practitioners were discussed.
\end{abstract}

Keyword: Financial security; Financial strains; Financial literacy; Female-headed households; Malaysia 